\title{
Treatment of Biogas for Use as Energy
}

\author{
J. Koller
}

\begin{abstract}
The biogas generated in biogas plants offers significant potential for the production of energy from renewable energy sources. The number biogas plants in the Czech Republic is expected to exceed one hundred in the near future. Substrates from agriculture, industry and municipal wastes are used for biogas production. Biogas plants usually use co-generation units to generate electricity and heat. Increased effectiveness can be achieved by using heat as a source of energy for producing renewable natural gas.
\end{abstract}

Keywords: renewable energy sources, biogas plant, anaerobic fermentation, organic substrates, heat utilisation, renewable natural gas.

\section{Introduction}

Biogas plants are significant sources of renewable energy. At present, there are 47 such facilities in operation in the Czech Republic, and in 2008 they produced 214 GWh of electric energy ( $0.3 \%$ of total consumption). Biogas production from various kinds of degradable substrates in biogas plants is technically feasible and economically viable. This resource offers considerable potential, and with complete utilization the capacity is in excess of one thousand MW. The primary application of biogas plants is in agriculture, enabling the utilization of all types of agricultural land for growing plants for energy, with guaranteed sales. Biogas plants help to develop rural areas and provide employment. The technology is suitable for villages and towns that can efficiently handle the processing of separated biologically degradable municipal wastes by means of suitably located biogas plants, leading to less waste disposal in landfills. The construction of biogas plants can reduce dependence on fossil fuel imports, and it is also in accordance with the commitment of the Czech Republic toward the EU to increase the proportion of energy produced from renewable resources. There could be a total of several hundred biogas plants in the Czech Republic within the next 20 years.

\section{Basic arrangement of a biogas plant}

Biogas production technology uses anaerobic fermentation, in the course of which organic substances degrade without access of air, and thus biogas is created. The most frequently-used method is wet mesophile fermentation at a temperature of $37-42^{\circ} \mathrm{C}$, and the solids content in the measured-out substrate and in the fermentor is lower than $12 \%$. A simplified scheme of a biogas plant is shown in Figure 1.
The first structure in a biogas station is the closed homogenization pit, where the separate raw materials are mixed together. In cases where fibrous substrates are added, disintegration to particles not exceeding $1 \mathrm{~cm}$ in size is necessary. For some types of raw material, particularly animal wastes, sanitation is prescribed. This is done by means of pasteurization in a closed container, where the waste is heated to $70{ }^{\circ} \mathrm{C}$ for at least 1 hour.

The mixed raw material is pumped once or twice a day into fermentors. Fermentors are closed cylindrical reactors, usually made of concrete or steel, thermally insulated and heated. The heating is done by hot water, either by means of heating coils or in a slurry/water exchanger. The material in the reactor is regularly agitated. For agitation, high-speed and slowspeed paddling agitators are used. The biogas that is produced is collected in a gasholder, which is most frequently designed as an integrated gasholder, which means that the gas is accumulated in the top section of the fermentor. From there it is drained away for purification and for further processing. Naturally, a solution with a separate gasholder can also be used. Fermentation is usually performed in two fermentors arranged one after the other. The size of the fermentor, the operational volume, the detention period and the fermentor load are selected in a way that ensures sufficient stabilization of the organic substances in the substrate and optimum biogas production. Usual detention periods lie between $30-50$ days. To complete the decomposition of the organic substances contained in the substrates, a stabilising basin (for final digestion) is added after the fermentors. The stabilising basin is not heated, but because biogas production is still proceeding, it is covered and connected to the gasholder system.

Biogas is a mixture of gases, the prevailing components of which are methane and carbon dioxide. Further additions are hydrogen, water vapour, hydrogen sulphide and other sulphuric compounds, a small 


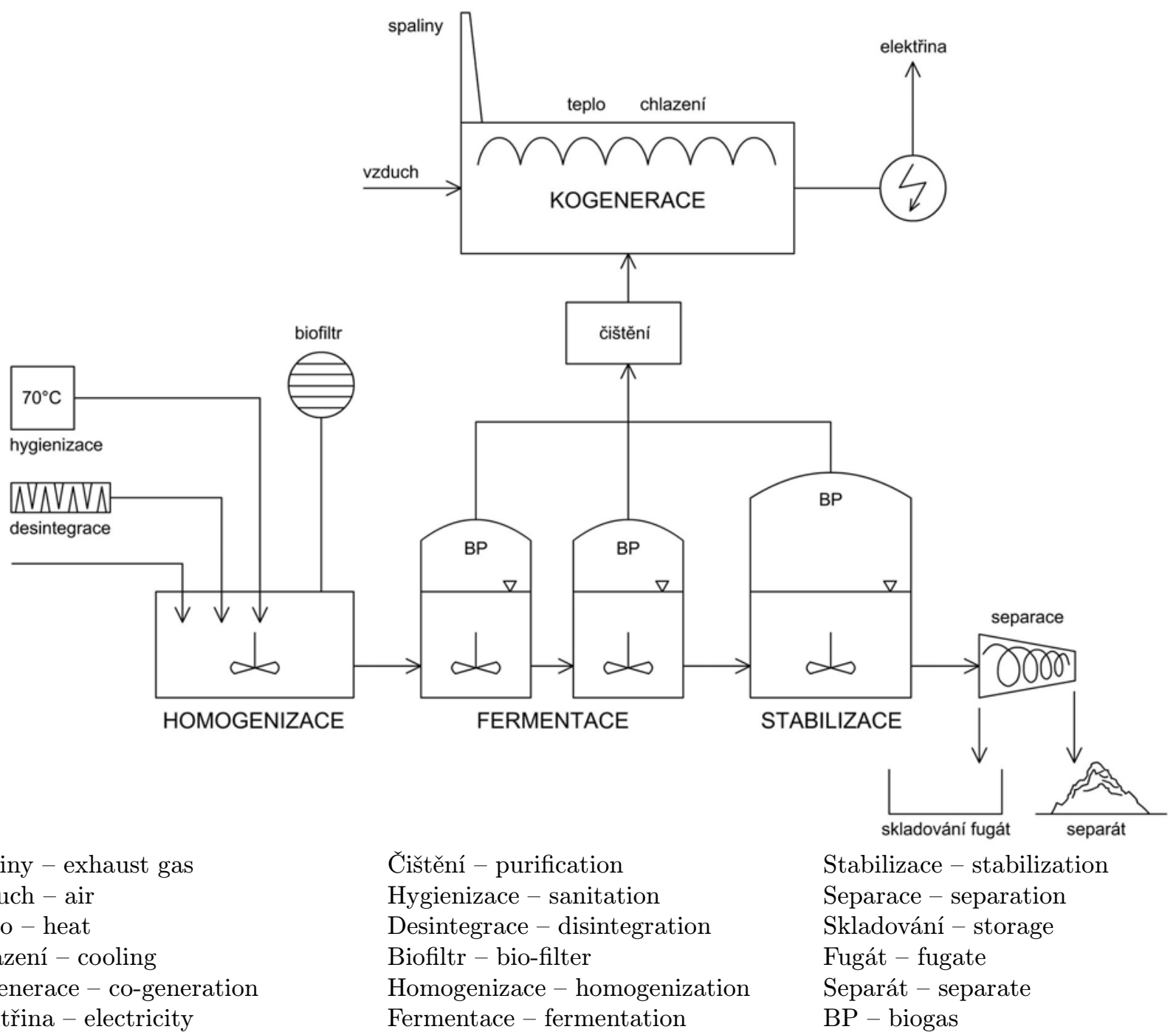

Fig. 1: Simplified scheme of a biogas plant

amount of nitrogen from the air, hydrocarbons, organic silicon and chlorine compounds. The composition of the biogas and the $\mathrm{CH}_{4} / \mathrm{CO}_{2}$ ratio are determined by the composition of the substrate, in particular by the proportion of carbohydrates, proteins and fats.

Before biogas is used in the co-generating unit, it is necessary to eliminate humidity and hydrogen sulphide in order to prevent corrosion of the engine. The water vapour condenses as water during biogas cooling. The hydrogen sulphide content is usually reduced by microbiological processes directly in the fermentor. If the concentration is too high, it is removed chemi- cally either by a special wash-out or by adsorption on active coal.

The co-generating unit consists of a gas combustion engine and an electric energy generator. The biogas is combusted and the mechanical energy that is created is partially converted to electricity, but the main part is carried away through the engine and exhaust gas cooling as heat. The usual electrical efficiency of a co-generating unit is $33-40 \%$, and it increases with size. The electrical energy that is produced is fed into the grid at long-term guaranteed subsidised purchase prices.

Table 1: Composition of substrate and biogas

\begin{tabular}{|l|c|c|c|c|}
\hline substrate & formula & TOD $(\mathrm{kg} / \mathrm{kg})$ & biogas production $\left(\mathrm{m}^{3} / \mathrm{kg}\right)$ & $\mathrm{CH}_{4}(\%)$ \\
\hline carbohydrates & $\mathrm{C}_{6} \mathrm{H}_{12} \mathrm{O}_{6}$ & 1.07 & $0.75-0.9$ & 53 \\
\hline fats & $\mathrm{C}_{18} \mathrm{H}_{34} \mathrm{O}_{2}$ & 2.89 & $1.1-1.6$ & 75 \\
\hline proteins & $\mathrm{C}_{6} \mathrm{H}_{14} \mathrm{~N}_{2} \mathrm{O}_{2}$ & 1.56 & $0.6-0.8$ & 70 \\
\hline
\end{tabular}

Note: TOD - total oxygen demand 
The decomposed substrate, flowing away as the residue after fermentation from the stabilising tank, is transferred to the separator. Either centrifugal machines or band screens are used for separation. The fermentation residue is divided into liquid fugate (usually $2 \%$ of the dry matter) and separate (approx. 28-35 \%). Separation can be improved by adding suitable polymeric organic flocculants. The separated solid is easily transported and can be used as a component for the production of compost, or can be worked into the soil. Fugate is a liquid organic nitrogeneous fertilizer which is applied to fields, etc. Because it can be applied only outside the growing season, it is necessary to provide storage for a period of approx. 110 days (the usual growing season) in a watertight storage tank, which is usually open. In some biogas plants there is no separation. The whole fermentation residue is stored, and it is worked into the soil as a fertilizer at a suitable time.

A major problem in operating a biogas plant is the development of malodorous substances, and their leakage must be prevented. The main point where odour emissions arise is the entry section of the biogas plant. This section must therefore be closed off, and is opened only for short periods of time to accept materials. The air mass from these facilities is exhausted and removed through an odour bio-filter, filled with moistened mass consisting of a mixture of peat, bark and other porous materials on which aerobic microorganisms grow. In this way the malodorous compounds are disposed of. There are no odour problems from a correctly designed and well-functioning biogas plant. Such problems arise when the plant is overloaded, in particular when processing animal wastes.

\section{Substrates}

In general, any suitably treated material containing a sufficient concentration of biologically degradable organic substances can be used in a biogas plant.

Animal materials from agriculture:

- pig manure

- cow manure, including litter

- manure and litter from horse, goat and rabbit keeping

- poultry droppings, including litter

Plant materials:

- maize silage

- grass biomass or hay (haylage)

- chaff and waste from cereal treatment

- potato leaves and potato peel

- beet leaves, including sugar beet leaves

Biologically degradable wastes:

- municipal waste from households, restaurants and cafeterias

- separated biological waste

- biologically degradable industrial waste
The fermentation process is also influenced by the content of degradable organic carbon and by the concentration of the nitrogen and sulphur compounds.

The main part of the nitrogen compounds in the substrates consists of organic bound nitrogen in proteins, which is converted into ammonia during anaerobic fermentation. Depending on the $\mathrm{pH}$ value in the fermentation mixture, the $\mathrm{NH}_{4}^{+} \leftrightarrow \mathrm{NH}_{3}$ balance is established. The ionic form is non-toxic, but the optimum $\mathrm{pH}$ value for methanogenic microorganisms (7-8), and a substantial part of the nitrogen is present as toxic dissolved $\mathrm{NH}_{3}$. The $\mathrm{C} / \mathrm{N}$ content in the substrates is therefore a significant monitored parameter. The optimum $\mathrm{C} / \mathrm{N}$ value is 20 , and there is a critical value of 10 , at which considerable inhibition of biogas production develops and the fermentation process can take place only under a low load. The $\mathrm{C} / \mathrm{N}$ content in different types of substrates is given in Table 2 .

Table 2: The $\mathrm{C} / \mathrm{N}$ ratio for typical substrates

\begin{tabular}{|l|c|}
\hline Substrate & $\mathrm{C} / \mathrm{N}$ \\
\hline blood & $3-4$ \\
\hline meat and bone meal & $4-7$ \\
\hline pig liquid manure & $12-15$ \\
\hline maize silage & $35-40$ \\
\hline straw & $20-40$ \\
\hline vegetable biomass & $40-100$ \\
\hline
\end{tabular}

Clearly, all animal wastes with a high protein content are hazardous; on the other hand, plant biomass has a substantially lower content of nitrogen compounds. An optimum substrate composition can be achieved by using a suitable mixture of the components that are available.

The source of sulphur in the materials may be dissolved inorganic sulphates or organic sulphur in some proteins. All these compounds are then converted to sulphides during anaerobic fermentation. If $\mathrm{Fe}^{2+}$ ions are present, insoluble FeS is created. The remaining sulphur appears in the biogas and in the fermentation liquid as gaseous hydrogen sulphide or during process overloading as much more malodorous organic sulphur compounds. Hydrogen sulphide and other sulphurcontaining compounds must be removed from biogas before it is burned, otherwise there is a risk of corrosion damage to the co-generation unit.

It is also very important to check the presence of heavy metals in the materials. Anaerobic fermentation endures relatively high concentrations without remarkable inhibition, but the presence of an excessive concentration of heavy metals would make it impossible to apply the fermentation residue subsequently as a fertilizer, and this would make the operation of the biogas plant totally impossible. 


\subsection{Biogas plant operation efficiency}

Currently-operated biogas plants burn biogas in cogenerating units and produce electricity which is compulsorily purchased at subsidised prices. The electric efficiency of these units is approx. $33-40 \%$ of the contained energy. The remainder is thermal energy, which falls off as hot water from motor cooling or is taken away as heat in the combustion gas. About $20 \%$ (in summer) or $33 \%$ (in winter) of the heat is used for heating the fermentors, and the rest of the heat is available for other purposes, or is disposed of as exhaust heat.

The efficiency of a biogas plant can be increased in several ways

- electricity production in energy peaks

- better heat utilization

- biomethane production.

\subsection{Production of electricity in energy peaks}

The current conditions for providing the subsidy for the construction of a biogas plant require continuous operation of the co-generation unit. According to the project of Skanska CZ, it would be more convenient to accumulate the biogas and to operate the co-generation unit and supply electricity into the grid only during energy peaks, when the price of electricity is much higher. Technically, this is not a problem, but it would require a change in the legislation, an agreement with the purchasers of electricity, and a modification of the subsidy conditions. This provision would take significant effect in the future, when the operation of several hundreds of biogas plants is anticipated. This naturally means an increase in investment costs, because the co-generation unit must have approximately double electric output.

\subsection{Increased heat utilization}

The excess thermal energy can be used in the following ways:

- hot water for heating agricultural structures or structures in a nearby village

- heat utilization for drying

- heat utilization from exhaust gas for steam production

- in tri-generation, where the energy is used to produce heat and cold; cold can be accumulated in the form of ice.

\subsection{Biomethane production}

The dominant components of biogas are $\mathrm{CH}_{4}$ and $\mathrm{CO}_{2}$, together with 4-6\% volume components of other ad- ditions. If $\mathrm{CO}_{2}$ and the additions are removed, we obtain a gas that does not practically differ from natural gas in its content. This gas can then be burned as a heating gas, used for driving motor vehicles, or added to the natural gas pipeline. In these applications, all energy contained in the biogas is utilized.

Several methods are known for separating $\mathrm{CO}_{2}$ from biogas. For the separation process, a water, glycol or ethanolamine wash-out can be used. There is also a cryogenic method in which $\mathrm{CO}_{2}$ is removed as dry ice. In technical practice, the technically and economically optimum method is PSA (Pressure Swing Adsorption), which uses special active coal working as molecular sieve. The adsorption runs under increased pressure (0.5-1 $\mathrm{MPa})$, the smaller $\mathrm{CO}_{2}$ molecules are captured, and the bigger $\mathrm{CH}_{4}$ molecules pass through the filter. Desorption of the captured gases takes place during the pressure decrease $(5 \mathrm{kPa})$.

Biomethane production from biogas has established itself in Sweden (for use in cars), and in Germany and Switzerland (biomethane is fed into gas pipelines). However, connecting a biogas plant to the gas pipeline requires relatively hard technical measures to be taken. High biomethane quality must be continuously monitored by means of chromatographic analysis. The heating power is modified by adding propane from an external source. A supply point equipped with a high pressure compressor has to be constructed. In the conditions of the Czech Republic, the implementation of biomethane production would have to be supported by technical and legislative modifications to the existing regulations.

\section{Conclusion}

The production and utilization of biogas from biogas plants offers significant potential for the production of energy from renewable resources. In the near future, a substantial increase in the number of biogas plants is anticipated, and they will utilize all kinds of suitable materials. Agricultural animal and plant wastes, energetic biomass, slurry from waste water treatment plants, and also industrial and municipal wastes with a high content of organic degradable materials can be used as substrates. A standard biogas plant burns biogas in a co-generation unit, and during this process electricity and heat are generated. An increase in the efficiency of biogas plant operation can be achieved by a better heat utilization, or by biomethane production.

\section{References}

[1] Straka F., et al: BIOPLYN. $2^{\text {nd }}$ ed. GAS s.r.o., Prague, 2006.

[2] Metodický pokyn „K podminkám schvalováni bioplynových stanic před uvedením do provozu“. Ministry of the Environment of the Czech Republic, Prague, September 2008. 
[3] Dohányos, M., Zábranská, J., Procházka, J.: Intenzifikace výroby bioplynu - předpoklady a praktické zkušenosti. In: Sbornik konference „Výstavba a provoz bioplynových stanic", November 9-10, 2008, Třeboň.

[4] Aufwind Schmack GmbH, Regensburg, Germany: Biometanová stanice $\mathrm{v}$ obci Pliening. In: Sbornik konference „Výstavba a provoz bioplynových stanic“, November 9-10, 2008, Třeboň.
Doc. Ing. Jan Koller, CSc.

Phone: +420 595953013

E-mail: koller@tomkar.cz

http://www.tomkar.cz

Tomášek SERVIS

Výstavní 135/107

70300 Ostrava-Vítkovice 